\title{
Phylogeny of Neckeropsis and Himantocladium (Neckeraceae, Bryophytina)
}

\section{Olsson, Sanna Elina}

2016-12

Olsson , S E , Enroth , J , Huttunen , S M \& Quandt, D 2016, ' Phylogeny of Neckeropsis and Himantocladium (Neckeraceae, Bryophytina) ' , Bryophyte Diversity \& Evolution , vol. 38 , no. 2 , pp. 53-70 . https://doi.org/10.11646/bde.38.2.4

http://hdl.handle.net/10138/174621

https://doi.org/10.11646/bde.38.2.4

publishedVersion

Downloaded from Helda, University of Helsinki institutional repository.

This is an electronic reprint of the original article.

This reprint may differ from the original in pagination and typographic detail.

Please cite the original version. 


\title{
Phylogeny of Neckeropsis and Himantocladium (Neckeraceae, Bryophytina)
}

\author{
SANNA OLSSON ${ }^{1,2^{*}}$, JOHANNES ENROTH ${ }^{3 *}$, SANNA HUTTUNEN ${ }^{4} \&$ DIETMAR QUANDT $^{5}$ \\ ${ }^{1}$ Department of Agricultural Sciences, University of Helsinki, P.O. Box 27, FI-00014 Helsinki, Finland \\ ${ }^{2}$ INIA Forest Research Centre (INIA-CIFOR), Dept. Forest Ecology and Genetics, Carretera de A Coruña km 7.5, E-28040 Madrid, \\ Spain \\ ${ }^{3}$ Department of Biological and Environmental Sciences and Botanical Museum, University of Helsinki, P.O. Box 7, FI-00014 Helsinki, \\ Finland \\ ${ }^{4}$ Department of Biology, FI-20014 University of Turku, Finland \\ ${ }^{5}$ Nees-Institute for Biodiversity of Plants, University of Bonn, Meckenheimer Allee 170, 53115 Bonn, Germany \\ *Corresponding author: Sanna Olsson, e-mail: sanna.olsson@helsinki.fi, tel.: +34634509635 or Johannes Enroth, e-mail: Johannes. \\ enroth@helsinki.fi,tel.:+3580294157792
}

\begin{abstract}
Two closely related tropical genera from the pleurocarpous moss family Neckeraceae are revised: the second largest genus in the family, Neckeropsis, currently with 29 species, and Himantocladium, comprising six species. Twenty-one species of Neckeropsis and five of Himantocladium were included in this study, which is based on phylogenetic analyses using sequence level data from the plastid (rps4)-trnT-trnL-trnF cluster and rpl16 as well as nuclear ITS1 \& 2. Neckeropsis appeared as polyphyletic. Neckeropsis s. str. comprises 12 species and a further four species, not included in the analysis, are tentatively retained in the genus based on morphology. Four new genera are segregated from Neckeropsis: Pengchengwua (with one species), Planicladium (two species), Pseudoparaphysanthus (five species), and Neckeromnion (five species). Neckeropsis gracilis is synonymized with Neckeromnion urocladum and reported for the first time from Laos. Four molecularly analyzed species are resolved in the Himantocladium s. str. clade, with a fifth species being retained solely on morphological basis. Himantocladium formosicum is transferred to Neckeropsis. Leaf-like paraphyses (ramenta), unique in Neckeropsis s. str., have evolved twice. In addition, the rare Noguchiodendron sphaerocarpum from the Himalayan region, the single species in its genus, was included in a phylogenetic analysis for the first time and was found to be closely related to the Asian genus Taiwanobryum.
\end{abstract}

Key words: convergent evolution; molecular systematics; Noguchiodendron; nomenclature; pleurocarpous mosses; taxonomy

\section{Introduction}

The Neckeraceae, a moss family with c. 200 species (Olsson et al. 2009b), belongs to the order Hypnales of the pleurocarpous mosses. In contrast to acrocarpous mosses, pleurocarps produce archegonia and thus sporophytes on reduced lateral branches rather than on the tips of main shoots. With ca. 5000 species pleurocarpous mosses, as defined by Bell et al. (2007), represent the major moss radiation comprising $\sim 50 \%$ of moss diversity. Within the Neckeraceae, three well-supported clades have been recognized in previous studies: the Neckera clade, the Thamnobryum clade and the Pinnatella clade (Olsson et al. 2009a), each of which was analysed subsequently with a more comprehensive taxon sampling by Olsson et al. (2010, 2011). Neckeropsis Reichardt and Himantocladium (Mitt.) M. Fleisch, on which the present paper focuses, are part of the Pinnatella clade that comprises mainly tropical Asiatic genera (Olsson et al. 2009a, 2010). A combination of morphological characters that distinguish this clade from other Neckeraceae include a strong costa, leaves with an inframarginal (rarely marginal) limbidium consisting of elongate cells, and a seta that is mammillose in its upper part. However, those characters are not ubiquitous in the clade and, in the neckeraceous context, only the mammillose seta is exclusive in it.

Neckeropsis was established by Reichardt (1868) based on the Neotropical Neckera undulata Hedw. Fleischer (1906-1908) considerably amended and expanded the generic concept, placing in Neckeropsis all species in the sections Paraphysanthus Spruce, Pseudoparaphysanthus Broth. and Taeniocladium Mitt. of Neckera Hedw. In the new 
circumscription, Neckeropsis had 21 species and was a pantropical genus most diverse in SE Asia. When Reichardt (1868) established Neckeropsis, he emphasized characters such as the roundish leaf cells, cap-like ("mützenförmig") calyptra with a lobed base, and perichaetial paraphyses that develop into linear, leaf-like structures. In Fleischer's concept, Neckeropsis consisted of plants with complanate, tetrastichous leaves, immersed capsules and cap-like calyptrae. Brotherus (1925) adopted Fleischer's subdivision and recognized a total of 36 species in Neckeropsis. Over the last 55 years, Neckeropsis has been taxonomically revised for the various parts of its geographic distribution: Asia and Pacific (Touw 1962, 1972, Touw \& Ochyra 1987, Ochyra \& Enroth 1989, Higuchi et al. 1989), neotropics (Sastre de Jesús 1987, Enroth 1995), and Africa (Enroth 1993, Enroth \& Magill 1994). The species currently recognized in Neckeropsis are listed in alphabetical order in Table 1.

TABLE 1. Species placed in Neckeropsis and Himantocladium before the present study. An asterisk $(*)$ denotes that the species was included in the present analysis.

\begin{tabular}{|c|c|}
\hline Neckeropsis & Himantocladium \\
\hline Neckeropsis andamana (Müll. Hal.) M. Fleisch.* & H. sect. Himantocladium \\
\hline N. beccariana (Hampe) Touw* & H. plumula (Nees) M. Fleisch.* \\
\hline N. boiviniana (Besch.) Card. & H. giulianettii (Broth.) M. Fleisch.* \\
\hline N. boniana (Besch.) Touw \& Ochyra & H. pacificum (Broth. \& Paris) Broth. \\
\hline N. calcicola Nog.* & H. submontanum Enroth* \\
\hline N. calcutensis (M. Fleisch.) Enroth* & H. implanum (Mitt.) M. Fleisch.* \\
\hline \multicolumn{2}{|l|}{ N. crinita (Griff.) M. Fleisch.* } \\
\hline N. cyclophylla (Müll. Hal.) S. Olsson, Enroth \& D. Quandt* & H. sect. Cyclophyllum \\
\hline \multicolumn{2}{|l|}{ N. disticha (Hedw.) Kindb.* } \\
\hline N. exserta (Hook.) Broth.* & H. formosicum Broth. \& Yas.* \\
\hline -- var. scrobiculata (Nees) Touw* & H. warburgii (Broth.) M. Fleisch. \\
\hline \multicolumn{2}{|l|}{ N. fimbriata (Harv.) M. Fleisch.* } \\
\hline \multicolumn{2}{|l|}{ N. foveolata (Mitt.) Broth.* } \\
\hline \multicolumn{2}{|l|}{ N. gracilenta (Bosch \& Sande Lac.) M. Fleisch.* } \\
\hline \multicolumn{2}{|l|}{ N. gracilis Nog.* } \\
\hline \multicolumn{2}{|l|}{ N. inundata (Broth.) Broth. } \\
\hline \multicolumn{2}{|l|}{ N. lepineana (Mont.) M. Fleisch.* } \\
\hline \multicolumn{2}{|l|}{ N. liliana (Ren.) Broth. } \\
\hline \multicolumn{2}{|l|}{ N. madecassa (Besch.) M. Fleisch.* } \\
\hline \multicolumn{2}{|l|}{ N. moutieri (Broth. \& Paris) M. Fleisch.* } \\
\hline \multicolumn{2}{|l|}{ N. nanodisticha (Geh.) M. Fleisch. } \\
\hline \multicolumn{2}{|l|}{ N. nitidula (Mitt.) M. Fleisch.* } \\
\hline \multicolumn{2}{|l|}{ N. obtusata (Mont.) Broth.* } \\
\hline \multicolumn{2}{|l|}{ N. pocsii Enroth \& Magill* } \\
\hline \multicolumn{2}{|l|}{ N. semperiana (Müll. Hal.) Touw* } \\
\hline \multicolumn{2}{|l|}{ N. spuriotruncata (Dus.) M. Fleisch. } \\
\hline \multicolumn{2}{|l|}{ N. submarginata Card. ex Touw } \\
\hline \multicolumn{2}{|l|}{ N. takahashii Hig. \& al.* } \\
\hline \multicolumn{2}{|l|}{ N. touwii Ochyra \& Enroth } \\
\hline N. undulata (Hedw.) Reichardt* & \\
\hline
\end{tabular}


Himantocladium was first recognized by Mitten (1868) as Neckera section Himantocladium Mitt. He included three species, Neckera implana Mitt., N. loriformis Bosch \& Sande Lac. and N. mucronata Bosch \& Sande Lac. Himantocladium was raised to generic status by Fleischer (1906-1908), who also added several species in it. Wijk et al. (1964) cited H. implanum (Mitt.) M. Fleisch. as the lectotype. In the original generic concept, Fleischer (19061908) recognized Himantocladium as an essentially Asian-Polynesian genus morphologically intermediate between the "Neckera-like" and the "Thamnobryum-like" taxa ("Neckereen" and "Thamnieen"). Fleischer emphasized in Himantocladium the combination of a dendroid habit, 8-ranked leaves, small [post-fertilization] perichaetial leaves and an exserted capsule with a small, cucullate calyptra.

The generic affinity and distinctions between Himantocladium and Neckeropsis were discussed by Touw (1962) and summarized in a taxonomic revision of Himantocladium by Enroth (1992a). The latter author considered Himantocladium as a genus morphologically intermediate between Neckeropsis and Pinnatella, and discussed the clearest generic distinctions. Enroth (1992a) further subdivided the eight accepted species in Himantocladium into two sections (Table 1). The section Himantocladium contained species with a synoicous sexual condition and essentially solid leaf cell walls, and the section Cyclophyllum Enroth had dioicous species with distinctly porose leaf cell walls at least in the basal lamina.

Subsequent analyses based on molecular data confirmed that the two genera are indeed closely interrelated, but also showed that neither of them is monophyletic (Olsson et al. 2010). Neckeropsis is characterized by the following combination of morphological features: plants non-stipitate [except N. cyclophylla (Müll. Hal.) S. Olsson, Enroth \& D. Quandt, N. formosica (Broth. \& Yasuda) S. Olsson, Enroth, Huttunen \& D. Quandt, and N. madecassa (Besch.) M. Fleisch.]; branching remote and irregular; stem central strand lacking; foliation complanate, pseudotetrastichous (cf. Touw 1962); post-fertilization growth of perichaetial leaves common; seta mostly short, thus capsules immersed. To these can be added a nearly consistent absence of apophysal stomata (except in N. cyclophylla and N. formosica), which are consistently present in Himantocladium s. str.

As in the generic concept of Fleischer (1906-1908), there is no single character that would separate Himantocladium, as currently understood, from the allied genera. Rather, it has the following combination of characters, unique among the Neckeraceae: plants stipitate, mostly frondose; stipe leaves appressed; stem central strand absent; leaves not deeply and regularly undulate; costa strong, single; no post-fertilization growth of perichaetial leaves; capsules exserted; and apophysal stomata few, usually just two or three per capsule. The generic placement of $H$. warburgii (Broth.) M. Fleisch. remains unclear, but it is not in Himantocladium s. str. (Olsson et al. 2011). Enroth (1994a) treated it in its original genus, as Neckera warburgii Broth., but it belongs in the Pinnatella clade and is not closely related to Neckera s. str. (Olsson et al. 2011).

As our earlier studies focused on resolving the backbone structure and genus-level relationships within the Neckeraceae, the taxon sampling was in most cases incomplete to reveal within-genus relationships. For example, only eight species out of the 28 that then were placed in Neckeropsis were included in Olsson et al. (2010). In this study, we aimed at gathering an almost complete taxon sampling for Neckeropsis and Himantocladium in order to better resolve the generic taxonomy and species relationships, and to elaborate the morphological evolution in Neckeropsis s. str.

\section{Material and methods}

Taxon sampling and molecular markers:-Phylogenetic analyses were performed on a slightly altered data set of Olsson et al. (2010) that was complemented by more taxa focusing on Neckeropsis and Himantocladium. In the current study, 21 species out of total of 29 species in Neckeropsis and five out of six Himantocladium species are included. The missing eight Neckeropsis species and Himantocladium pacificum could not be included due to lack of adequately fresh material. In addition, we included Noguchiodendron sphaerocarpum (Nog.) T.N. Ninh \& Pócs, the single species in its genus (Ninh \& Pócs 1981) and not included in phylogenetic analyses previously. For this selection of taxa, we sequenced three genomic regions: the internal transcribed spacer of nuclear ribosomal DNA (ITS1 \& 2), the plastid (rps4)-trnT-trnL-trnF cluster (including the 3' of the rps4 gene), and the group II intron in rpl16 (plastid).

DNA isolation, PCR-amplification and sequencing:-DNA was extracted using the DNeasy ${ }^{\circledR}$ Plant Mini Kit from Qiagen (Qiagen $\mathrm{GmbH}$, Germany) following the manufacturer's protocol. Methods of cleaning and grinding of plants prior to extraction and PCR amplification of genetic regions followed Olsson et al. (2009a, 2009b). Gel cleaned PCR products were sequenced by Macrogen Inc., South Korea (www.macrogen.com). Sequences were edited manually with PhyDE® v0.997 (Müller et al. 2005) and primer sequences were eliminated. All sequences are deposited 
in EMBL (European Molecular Biology Laboratory); accession numbers are listed together with voucher information (Appendix 1).

Sequence analyses and phylogenetic analyses:-Alignment of the sequence data was performed manually in PhyDE® v0.997 (Müller et al. 2005), based on the criteria laid out in Kelchner (2000) and Olsson et al. (2009b), using the alignment of Olsson et al. (2010) as scaffold. The reported hairpin associated inversion in the trnL-F intergenic spacer (IGS) (Quandt \& Stech 2004) was positionally isolated in the alignment and included in the analysis as reverse complement in order to gain information from substitutions within the detected inversion, as discussed in Quandt et al. (2003) and Borsch \& Quandt (2009). Alignments are available on request from the authors. Indels were incorporated as binary data using a simple indel coding (SIC) strategy (Simmons \& Ochoterena 2000) as implemented in SeqState (Müller 2005).

Maximum likelihood (ML) analyses were performed with RAxML (Stamatakis 2006; Stamatakis et al. 2008) on CIPRES Science Gateway (Miller et al. 2010). The models GTR $+\Gamma$ and GTR $+C A T$ were tried out, and since GTR + CAT resulted in slightly better support values, it was was used for the final analyses. Bootstrap analysis was performed with 1000 ML bootstrap replicates on the concatenated data matrix. The data matrix set was divided in a partition of subsets according to the boundaries of the genetic regions.

Bayesian analyses were performed with MrBayes v3.2.6 (Huelsenbeck \& Ronquist 2001), applying the GTR $+\Gamma+I$ model for the sequence data and the restriction site model for the binary indel partition. To allow for possible deviating substitution models for the different regions, the data set was further divided into three sequence partitions (partition 1: rps4-trnF; partition 2: rpl16; partition 3: nuclear DNA). The a priori probabilities supplied were those specified in the default settings of the program. Posterior probability (PP) distributions of trees were calculated using the Metropoliscoupled Markov chain Monte Carlo (MCMCMC) method and the search strategies suggested by Huelsenbeck et al. $(2001,2002)$. Ten runs with four chains $\left(1 \times 10^{6}\right.$ generations each) were run simultaneously. Chains were sampled every 1000 generations and the respective trees written to a tree file. Tracer v1.6 (Rambaut et al. 2014) was used for the output of the model parameters to examine the sampling and convergence results. Calculations of the consensus tree and of the posterior probability of clades were performed based upon the trees sampled after the chains converged ( $<$ generation 50 000). Consensus topologies and support values from the different methodological approaches were compiled and drawn using TreeGraph2 (Stöver \& Müller 2010). Phylogenetic analyses were conducted on each partition separately. No incongruence was detected, therefore the analyses were performed on the combined data matrix.

\section{Results}

Alignment and sequence analyses:-Before analysing the matrix, 21 hotspots with poly-homonucleotide repeats were recognized and excluded from the analyses following Olsson et al. (2009b). The resulting alignment contained 4038 positions of which 1444 positions belonged to the (rps4)-trnT-trnL-trnF partition, 1680 positions to the nuclear ribosomal partition and 914 positions to the rpll6 partition. Of all characters 800 (19.8\%) were variable and 482 $(11.9 \%)$ parsimony informative. When the information based on indel coding was included, the data matrix included 4548 positions, of which 1307 (28.7\%) were variable and 721 (15.9\%) parsimony informative.

Phylogenetic analyses:-The best scoring ML tree with bootstrap support values showed no topological conflict with the results from the Bayesian inference. Therefore, only the BI tree is illustrated (Fig. 1), with posterior probabilities (PP) indicated and complemented with bootstrap values (BS) of the ML analysis when applicable. Values resulting from analyses without indel coding approach precede the values from analyses with the SIC-matrix included. Thus support values from the different analyses will be referred to in the text following the scheme: (PP / PPsic / BS / BSsic).

The monophyly of the Neckeraceae is fully supported in the Bayesian analyses (PP 1/1, BS 82 / 86). The Neckeraceae species that belong to the outgroups in the present analyses confirm the within-family structure found in earlier analyses: a maximally supported Neckera-clade (PP 1 / 1, BS 100 / 100,) (including Neckera, Forsstroemia Lindb., Leptodon D. Mohr. and Alleniella S. Olsson, Enroth \& D. Quandt) and a Thamnobryum-clade (PP 0.97 / 0.99 , BS $67 / 78$ ) that also includes Homalia Brid., Pendulothecium Enroth \& S. He and Porotrichodendron M. Fleisch. 


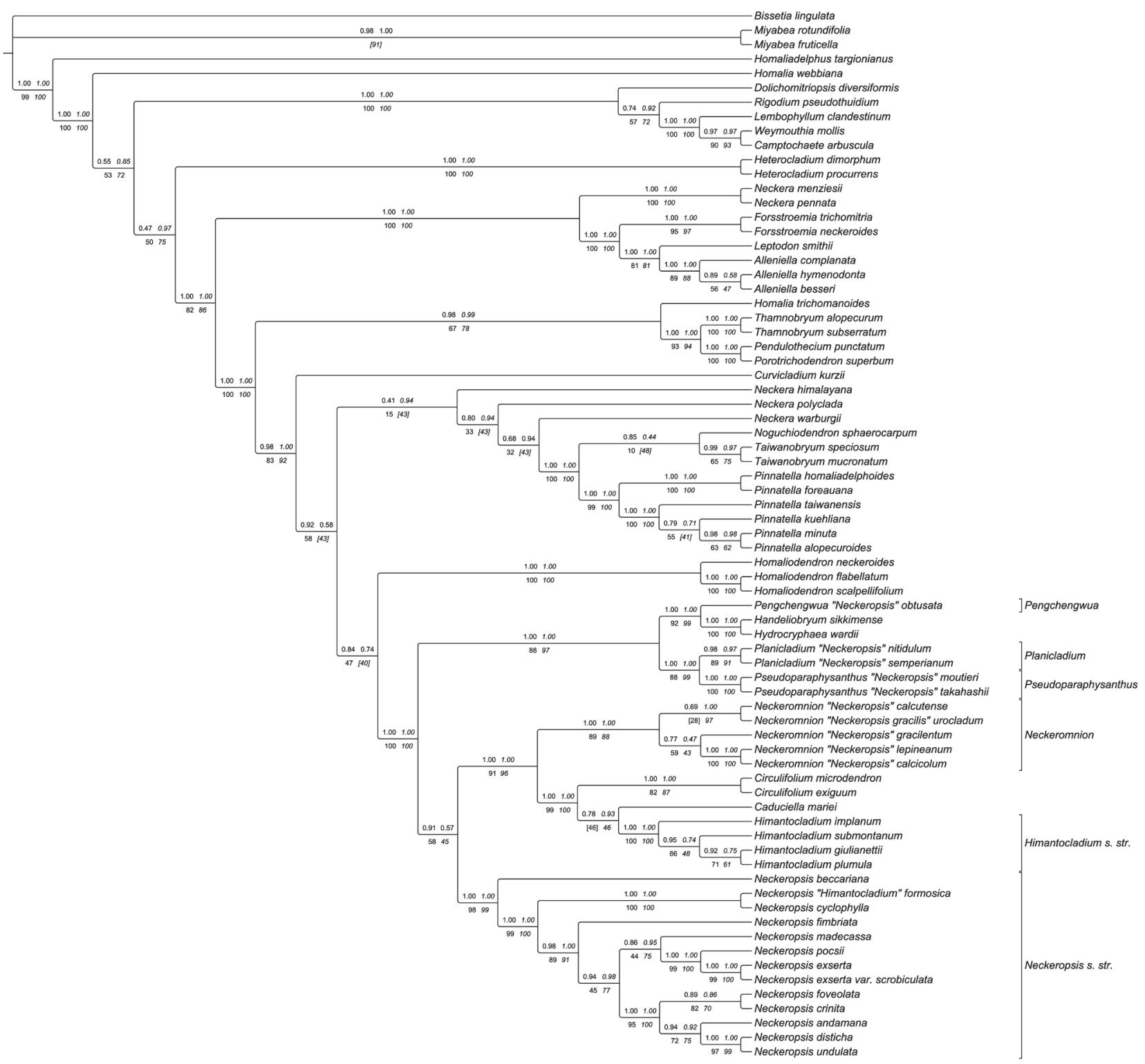

FIGURE 1. Phylogenetic relationships of selected Neckeraceae taxa based on rps4-trnT-trnL-trnF, rpl16 and ITS1 \& 2 sequences. The tree represents the majority consensus of trees sampled after stationarity in the Bayesian analysis. PP values from the Bayesian inference are indicated above (first without indels, then with indel data), the corresponding bootstrap values of the parsimony analysis below (first without indels, then with indel data), when applicable.

Curvicladium kurzii, the single species in its genus, is sister (PP $0.98 / 1$, BS 83 / 92) to the ingroup, the socalled Pinnatella-clade. The three "Neckeras" in this clade, i.e. N. himalayana Mitt., N. warburgii and N. polyclada Müll. Hal. will be included in a forthcoming analysis by us, focusing on Neckera s.l. Within the ingroup, several well supported clades are identified. Noguchiodendron is resolved as sister to Taiwanobryum although without support (PP 0.85 / 0.44, BS - / - ). Pinnatella forms a clade with very high support (PP 1 / 1, BS 99 / 100). Homaliodendron receives full support in all analyses. The rest of the species form the clade (PP 1/1, BS $100 / 100)$ that is the focal point of this paper. It includes members of Neckeropsis, Circulifolium S. Olsson, Enroth \& D. Quandt, and Himantocladium as well as Handeliobryum sikkimense (Paris) Ochyra, Hydrocryphaea wardii Dixon and Caduciella mariei (Besch.) Enroth.

Neckeropsis and Himantocladium are both polyphyletic. Four Himantocladium species, H. implanum, H. submontanum Enroth, H. giulianettii (Broth.) M. Fleisch. and H. plumula (Nees) M. Fleisch. form a fully supported Himantocladium s. str. clade. Neckeropsis species are resolved in five well supported clades (Fig. 1): 1) a Neckeropsis s. str. clade (PP 1 / 1, BS 98 / 99), which also includes Himantocladium formosicum Broth.; 2) a Neckeromnion clade with Neckeropsis calcutensis (M. Fleisch.) Enroth, N. gracilis Nog., N. gracilenta (Bosch \& Sande Lac.) M. Fleisch., $N$. lepineana (Mont.) M. Fleisch. and N. calcicola Nog. 3) a fully supported Pseudoparaphysanthus clade with $N$. 
moutieri (Broth. \& Paris) M. Fleisch. and N. takahashii Higuchi, Iwatsuki, Ochyra \& Li, and 4) a Planicladium clade comprising N. semperiana (Hampe ex Müll. Hal.) Touw and N. nitidula (Mitt.) M. Fleisch. (PP 0.98 / 0.97, BS 89 / 91). The two last mentioned clades are together forming a clade that is sister to a well-supported 5) Pengchengwua "Neckeropsis" obtusata - Handeliobryum - Hydrocryphaea clade (PP 1 / 1, BS 92 / 99). The Neckeromnion clade is sister to a fully supported Circulifolium-Caduciella-Himantocladium clade, and together these two form a clade with the Neckeropsis s. str. clade, though only with moderate (PP 0.91 / 0.57, BS 58 / 45) support.

\section{Discussion}

The phylogenetic results support the division of Neckeropsis s. l. into five monophyletic lineages. The largest one, with 21 species, comprises Neckeropsis s. str., while the four remaining clades are recognized as new genera, which are discussed and described below. A clade including Neckeropsis gracilenta, N. calcicola and N. calcutensis was already identified by Olsson et al. (2010), but taxonomic changes were pending for the more comprehensive analyses provided here.

Neckeropsis s. str.:-Of the taxa included in our study, Neckeropsis andamana (Müll. Hal.) M. Fleisch., $N$. beccariana (Hampe) Touw, N. crinita (Griff.) M. Fleisch., N. cyclophylla, N. disticha (Hedw.) Kindb., N. exserta (Hook.) Broth., N. exserta var. scrobiculata (Nees) Touw, N. fimbriata (Harv.) M. Fleisch., N. formosica (Himantocladium formosicum Broth. \& Yasuda), N. foveolata (Mitt.) Broth., N. madecassa, N. pocsii Enroth \& Magill and N. undulata are placed in Neckeropsis s. str. Because of the polyphyly of Neckeropsis s. l. the morphological delimitation used in early treatments by Reichardt (1868) and Fleischer (1906-1908) requires some adjusting (see below).

Biogeography:-Even in its new circumscription, Neckeropsis s. str. remains a pantropical genus that has its highest species diversity in Asia. The topology of the Neckeropsis s. str. clade does not convey a clear biogeographic pattern. Six of the sequenced species ( $N$. beccariana, N. fimbriata, $N$. formosica, $N$. exserta, N. crinita, $N$. andamana) are exclusively Asian and are scattered across the clade without a single exclusively Asian species pair. Neckeropsis beccariana is endemic to Borneo and N. formosica has been recorded from Taiwan, Laos and the Philippines (Enroth 1996); the record of the latter from a completely different climate and environment in Xizang (Wu 2011) requires verification. The remaining three species have wider distributions in the continental SE Asia, $N$. andamana being known also from the Andamans and Philippines, but none of them are known from the Indonesian archipelago.

We did not have adequately fresh material available of Neckeropsis boiviniana (Besch.) Cardot, $N$. boniana (Besch.) Touw \& Ochyra, N. inundata (Broth.) Broth., N. liliana (Renauld) Paris, N. nanodisticha (Geh.) M. Fleisch., $N$. submarginata Card. ex Touw, N. touwii Ochyra \& Enroth and N. spuriotruncata (Dusén) M. Fleisch. Of those, $N$. boniana, N. submarginata and $N$. touwii are here transferred to Pseudoparaphysanthus based on morphology (see below), while the other five are retained in Neckeropsis s. str. incertae sedis.

Neckeropsis boiviniana is a narrow endemic, known only from three specimens collected in northern Madagascar and the small island of Nosy Bé NW of Madagascar. The type collection dates back to 1851 and the most recent one to 1972 (Enroth 1993). The name Neckeropsis inundata was reduced into synonymy under N. disticha by Sastre-De Jesús (1987), but Enroth (1995) thought there were adequate morphological differences to justify recognizing $N$. inundata as a distinct species. It is known only from the original material collected in 1900 along Río Juruá in the W Amazonas region (cf. Enroth 1995). Neckeropsis nanodisticha was described in detail by Touw (1962). It is known from Indonesia, Papua New Guinea and Queensland in Australia. Its specialized paraphyses (ramenta) represent the same subtype as those of $N$. crinita (Merced-Alejandro \& Sastre-De Jesús, 2009); thus $N$. nanodisticha probably belongs in Neckeropsis s. str. Neckeropsis liliana and N. spuriotruncata are rare African species. Neckeropsis liliana is known from W and Central Africa: Ivory Coast, Ghana, Cameroon, Central African Republic and the Democratic Republic of the Congo (= Zaire; Enroth 1993). All of the known material of the species is quite old, collected between 1895 and 1936. Neckeropsis spuriotruncata is reported from Ivory Coast, Cameroon, Gabon, Republic of Congo (Enroth 1993), and from Guinea and the Democratic Republic of the Congo (Ellis et al. 2016); all the known material is old. Based on morphology, Enroth (1993) concluded that N. spuriotruncata, N. liliana and N. madecassa form a coherent group, for example by having identical sporophytes. If the two former indeed are close to $N$. madecassa, they belong in Neckeropsis s. str.

Neckeropsis madecassa is known from Africa (Cameroon, Gabon, Zaire, Madagascar, Réunion; Enroth 1993), while the morphologically variable $N$. cyclophylla ranges from the Seychelles in the Indian Ocean through tropical and subtropical Asia to northern Australia and Samoa in the east (Enroth 1992a).

Neckeropsis pocsii, the sister species of the SE Asian N. exserta, is known only from the Comoro Islands in the 
Indian Ocean (Enroth \& Magill 1994). Its gametophyte most closely resembles that of $N$. disticha, but the two species are not closely related.

The remaining clade of six species is also a biogeographical mélange. Neckeropsis foveolata and $N$. disticha, not closely related to each other, are distributed in Central and South America and Africa; N. crinita is the closest relative of $N$. foveolata but is exclusively distributed in SE Asia. Neckeropsis undulata is the sister of $N$. disticha and the single species in the genus restricted to Central and South America (plus the Caribbean Islands and Florida; Buck 1998).

Morphology and evolutionary trends:-In contrast to genera such as Himantocladium, Taiwanobryum and Pinnatella, species of Neckeropsis s. str. lack clearly differentiated stipes and fronds. Neckeropsis cyclophylla, $N$. formosica and $N$. madecassa are sometimes indistinctly stipitate, but the stipe bears only slightly differentiated leaves (as compared to the upper leaves). The leaf base is distinctly widened in $N$. formosica, $N$. foveolata, $N$. fimbriata, $N$. exserta, N. crinita, $N$. andamana and $N$. undulata, and with a distinct basiscopic auricle in N. fimbriata, N. madecassa, $N$. crinita, $N$. exserta, $N$. foveolata, $N$. andamana and $N$. undulata. Elsewhere in the Neckeraceae, such auricles are encountered only in Pinnatella homaliadelphoides Enroth, S. Olsson, S. He, Shevock \& D. Quandt (Enroth et al. 2010), which in an intriguing way "mimics" the genus Homaliadelphus of the Miyabeaceae (Olsson et al. 2009b).

The leaves are deeply and regularly undulate in Neckeropsis foveolata, N. fimbriata, N. crinita, N. exserta, N. andamana and $N$. undulata. It is noteworthy that in the first diverging lineages in Neckeropsis s. str. comprising of $N$. beccariana, $N$. cyclophylla, $N$. fimbriata, and $N$. formosica, only $N$. fimbriata has such undulate leaves. Evolution of undulate leaves appears to be a recurring trend in various neckeraceous lineages, particularly in Neckera s. str., Exsertotheca S. Olsson, Enroth \& D. Quandt and Alleniella (cf. Olsson et al. 2011) in addition to Pengchengwua, Neckeromnion (both established in the present paper) and Neckeropsis s. str. In these taxa, the undulations are typically lunate, or semi-circular, and it can be assumed that they are able to retain water on the often pendent gametophytes. It is also clear however that without a single exception in the Neckeraceae, when the leaves are deeply and regularly undulate they are also glossy, often strongly so. In our opinion, this clearly suggests that such undulate, glossy leaf surfaces have some kind of a photobiological function, as the leaf surfaces reflect light (and heat) to various directions and may enhance photosynthesis in conditions of reduced light availability.

Within the genus there is a shift from dioicous sexual condition in first diverging species to autoicy and/or synoicy in the crown clade. The four species that branch off first ( $N$. beccariana, $N$. cyclophylla, $N$. formosica, $N$. fimbriata) are dioicous. Crown clade taxa from Neckeropsis madecassa onwards are autoicous; N. pocsii and N. undulata are at least partly synoicous, and $N$. disticha is exclusively so. The same trend from dioicy to autoicy was observed by Olsson et al. (2011) in the genus Alleniella. It is well established that autoicous mosses reproduce sexually and produce sporophytes and thus spores much more frequently than dioicous ones. Recently Laenen et al. (2016) showed that shifts to bisexuality may increase diversification rates in liverworts. They suggested that this could be related to higher dispersal capacity and higher potential for long distance dispersal and allopatric speciation. Sexual reproduction enhances dispersal and genetic variability, which may have been the driving evolutionary force behind the trend.

Development and structure of perichaetial paraphyses in Neckeropsis s. str. have some unique features. Most mosses have sterile filaments called paraphyses intermixed with antheridia in perigonia and with archegonia in perichaetia. Paraphyses are almost always uniseriate and thread-like. Six species of Neckeropsis s. str. have in their post-fertilization perichaetia wider, bi- to multiseriate and "leaf-like" structures that have been called ramenta (in Latin ramentum $=$ a thin membranous or chaffy flattened scale; Stearn 1993). Their origin has been uncertain, as they have been interpreted as ligulate perichaetial leaves (cf. Touw 1962) or modified, multiseriate paraphyses.

Merced-Alejandro \& Sastre-De Jesús (2009) studied the ontogeny and structure of these alleged perichaetial paraphyses in several species of Neckeropsis. They showed that the ramenta found in the perichaetia of N. andamana, $N$. crinita, $N$. disticha, $N$. fimbriata, $N$. nanodisticha and $N$. undulata are indeed derived from uniseriate paraphyses and are thus not homologous with perichaetial leaves. Those authors recognized three types of fully developed ramenta based on their development and structure. In $N$. nanodisticha and $N$. crinita the ramenta are relatively thin and fully developed at early mature stage in the developmental sequence. In $N$. undulata and $N$. disticha they develop further, being narrowly ligulate when mature and representing middle mature stage. The widest, ligulate to lanceolate ramenta are present in $N$. andamana and $N$. fimbriata and they were interpreted as representing late mature stage.

Of the six species with ramenta, we were able to include five in this analysis: N. crinita, N. fimbriata, N. andamana, $N$. disticha and $N$. undulata. With the exception of $N$. fimbriata, they all are placed in the crown clade (Fig. 1), which also contains $N$. foveolata, which has plesiomorphic, uniseriate paraphyses. Neckeropsis disticha and N. undulata are resolved as sister taxa and their ramenta are similar (middle mature stage). Neckeropsis crinita is resolved as sister to $N$. foveolata and it has thin, early mature stage ramenta, so it is plausible to hypothesize that in this clade such ramenta represent the first evolutionary stage and that the other two types of ramenta (in $N$. andamana, $N$. disticha and $N$. 
undulata) are more advanced. Neckeropsis fimbriata, however, has mature stage ramenta (as does N. andamana) and it does not belong in this clade, so such ramenta must have evolved twice.

Within the Neckeropsis s. str. clade there is an evolutionary trend leading from species with relatively long setae and exserted capsules to ones with immersed capsules and very short setae. All species in the crown clade, N. foveolata, $N$. crinita, $N$. andamana, $N$. disticha and $N$. undulata, have a derived condition, very short setae and thus capsules immersed among perichaetial leaves. Of the rest of the species, excluding $N$. beccariana, for which sporophytes are unknown, N. madecassa and N. fimbriata have immersed capsules (De Sloover 1977, as N. hookeriacea (Müll. Hal. ex Dusén) M. Fleisch.), while N. cyclophylla (Wu 2011, as Himantocladium cyclophyllum), N. formosica (Noguchi 1950 as Himantocladium formosicum), N. pocsii (Enroth \& Magill 1994), and N. exserta (Touw 1962) have longer setae and exserted capsules. Notably, all species with ramenta have immersed capsules, so it appears clear that ramenta have evolved to shelter the maturing capsules.

Otherwise, there is little variation in the sporophyte structure. In all species the capsules are erect and symmetric, ovoid to ellipsoid or cylindric, their length varying from 1.0 to c. $1.5(-1.8) \mathrm{mm}$ without clear differences among the species. The operculum is conical and shortly rostrate. The peristome varies little among the species, having narrowly lanceolate, densely papillose and often partly perforated exostome teeth and linear, papillose and perforated endostome segments on a low basal membrane. The peristome of $N$. disticha was illustrated by Florschütz-De Waard (1986), that of N. undulata by Buck (1998), that of N. madecassa by De Sloover (1977 as N. hookeriacea), and that of N. crinita by Touw (1962).

The absence of apophysal stomata in Neckeropsis, considered an unequivocal distinction from Himantocladium by Enroth (1992a) no longer holds, because the early diverging $N$. cyclophylla and $N$. formosica have 2 or 3 phaneroporous stomata per capsule. All other species of Neckeropsis s. str. lack stomata.

Himantocladium s. str.:-In the current analysis Himantocladium s. str. becomes a morphologically coherent group, corresponding to Enroth's (1992a) Himantocladium sect. Himantocladium (Table 1). Himantocladium cyclophyllum (Olsson et al. 2010) and H. formosicum (Fig. 1) form a monophyletic clade in Neckeropsis s. str. Both of them are dioicous and have leaves with distinctly porose walls in the basal laminal cells, and with rather irregularly crenate apices. All of the five species in Himantocladium s. str. are synoicous (and thus frequently with sporophytes), have solid-walled leaf cells, and crenulate leaf apices. The sporophytes are remarkably uniform, the erect, symmetric capsules being exserted on a seta 1.0-2.0(-2.5) $\mathrm{mm}$ long and slightly mammillose in the upper part. There are no consistent interspecific differences in the peristome, which closely resembles that of several other neckeraceous genera, such as Neckeropsis s. str. and Pinnatella.

Whether the species of Himantocladium are indeed functionally synoicous is unclear. Akiyama (1993) observed that in the gametoecia of $H$. plumula there were mature archegonia intermixed with "totally immature" antheridia. One of us (J. Enroth) has made similar observations. This suggests some kind of "protogyny"; Akiyama (1993) used the term "sequential synoicy". It is not known if it is consistent and if it indeed serves to hamper self-fertilization.

Enroth (1992a) considered Himantocladium to be morphologically intermediate between Neckeropsis and Pinnatella. The analysis by Olsson et al. (2010) included H. implanum and H. plumula and they formed a clade with the unispecific genus Caduciella Enroth and Circulifolium, which was segregated from Homaliodendron in the same paper. That result is supported by the present analysis; Pinnatella in its current circumscription and Neckeropsis s. str. are in fact more distant relatives of Himantocladium.

Himantocladium is essentially a SE Asian - Oceanian genus. Two of the species have wide distributions, while three of them are more narrowly distributed. Himantocladium implanum has been recorded from the Ascension Island in the mid-Atlantic (Enroth 1992a), but its main range extends from Papua New Guinea (New Britain) to the Society Islands. Himantocladium plumula has a wider distribution in Asia, being known from Japan and China through Indonesia to Australia (Queensland), and eastwards to the Society Islands. It is however much less frequent than $H$. implanum in Oceania.

Himantocladium giulianettii is known from Indonesia, New Guinea and the Society Islands, but without any interjacent records between the two latter areas. Himantocladium submontanum is restricted to Indonesia and New Guinea (Akiyama 1993), while H. pacificum (Broth. \& Paris) Broth., the single species not sampled for this study, is endemic to New Caledonia.

Pengchengwua obtusata:-Pengchengwua obtusata is nested in a small but heterogeneous SE Asian clade with two other unispecific genera: the rheophytic Handeliobryum and Hydrocryphaea. Broadly speaking, this clade of just three taxa covers the range of gametophytic as well as sporophytic variation present in the whole Neckeraceae. The gametophytes of Handeliobryum sikkimense are robust, dendroid, distinctly stipitate and very rigid, and the leaves have a strong, single costa (Ochyra 1986). These characters were taken to suggest a close relationship with Pinnatella (Ochyra 1986). However, sporophytes were found only later and they resemble those of Thamnobryum Nieuwl. and 
members of the "Poro-clade" of the Neckeraceae (Olsson et al. 2011), having, e.g., long setae and nearly unreduced, hypnoid peristomes (Ochyra \& Shevock 2012).

The gametophytes of Hydrocryphaea wardii Dixon are not drastically different from those of Handeliobryum, but the sporophytes are (Shevock et al. 2006). The seta is very short, rendering the capsule immersed among the perichaetial leaves. The peristome is reduced, of the "neckeroid" type, which is also encountered in e.g. Pinnatella, Himantocladium and Neckeropsis s. l. (e.g. Enroth, 1994b). Also Pengchengwua obtusata has immersed capsules and a "neckeroid" peristome. Its gametophytes, however, differ strongly from those of Handeliobryum and Hydrocryphaea, being non-stipitate and having undulate, mostly complanate leaves with a fairly weak costa reaching only to midleaf. Handeliobryum and Hydrocryphaea have some gametophytic morphological adaptations to rheophytic habitats (Ochyra 1986, Enroth 1999, Shevock et al. 2006). Pengchengwua however grows on tree trunks, branches and rocks (Touw 1962, Wu 2011) and lacks all such adaptations.

Although a distinct species, P. obtusata has no striking generic distinctions from the undulate-leaved species in Neckeropsis s. str., or from Neckeromnion, which it resembles also in being dioicous. The costa reaching to about midleaf and the mostly rounded leaf tips are characteristic, as are the deeply immersed capsules. A further character worth noting is the presence of short, few-celled, filiform pseudoparaphyllia which we have not observed in Neckeropsis s. str. or Neckeromnion. The pseudoparaphyllia of Hydrocryphaea are also very small, less than $100 \mu \mathrm{m}$ long, but they are not filiform (Shevock et al. 2006). Those of Handeliobryum are leaf-like and up to c. $200 \mu \mathrm{m}$ long (Ochyra 1986), so small pseudoparaphyllia does not qualify as a synapomorphy in this clade.

Pengchengwua is a SE Asian taxon, known from Japan through southeastern China (including Taiwan) to northern Vietnam. The rheophytic Handeliobryum and Hydrocryphaea have narrower distributions. Handeliobryum was considered a "typical Sino-Himalayan endemic genus" by Ochyra \& Shevock (2012), being known from Nepal, NE India, and Xizang, Yunnan and Sichuan in China. Hydrocryphaea has a similar but slightly wider general distribution, ranging from NE India through Yunnan to Laos and Vietnam (Shevock et al. 2006).

Planicladium clade:-The two SE Asian species Planicladium semperianum and P. nitidulum (cf. Wu 2011, as Neckeropsis semperiana and $N$. nitidula) have a similar appearance, both being strongly glossy plants with complanate, non-undulate, non-auriculate and often apiculate leaves. Neckeropsis beccariana, which is endemic to Borneo (Touw \& Ochyra 1987, Akiyama 1992, as Neckeropsis fleischeri (Dix.) Touw) has a somewhat similar habit and leaf shape, but it has the laminal cells in the basiscopic side of the leaves much longer than in the acroscopic side, a feature not present in $N$. semperiana or $N$. nitidula. The latter two species form a morphologically and biogeographically coherent group that we recognize at the generic level.

Planicladium semperianum is a tropical species known from S China, Vietnam and the Philippines (Wu 2011). The distribution of $P$. nitidulum partly overlaps that of $P$. semperianum in China, but its range extends further northwards, as it is known also from Korea and Japan (Wu 2011).

Pseudoparaphysanthus clade:-Neckeropsis boniana, N. submarginata, N. touwii, N. takahashii, and N. moutieri were placed in Neckeropsis sect. Pseudoparaphysanthus by Touw \& Ochyra (1987) and Ochyra \& Enroth (1989). The section comprised SE Asian, mostly rheophytic species (cf. Enroth 1999). Neckeropsis takahashii and N. moutieri are included in the genus Pseudoparaphysanthus based on the molecular data used in this analysis. These two species share many morphological similarities, such as inframaginal, bi- to multistratose limbidia in the leaves, and they have in fact sometimes been confused with each other (cf. He \& Zhang 2007).

In the lack of fresh material for sequencing, $N$. boniana, $N$. submarginata and $N$. touwii are transferred to Pseudoparaphysanthus on morphological grounds. All of these five species have very distinct and sharply demarcated limbidia reaching to leaf apex or nearly so along both leaf margins, and consisting of elongate, thick-walled cells. Further distinctions from Neckeropsis s. str. are the generally obtuse or broadly acute leaf apices, the very strong costa reaching to leaf apex or ending just a few cells below it, and the lack of basal auricles in the leaves. Limbidia are present in several species of Neckeropsis s. str., but they are always more distinct only along the basiscopic leaf margin and can be quite indistinct or absent in the acroscopic one; also, the leaf costae in Neckeropsis s. str., although fairly strong, end well below the leaf apex in almost all species, the leaf apices are typically rounded to truncate, and most of the species have distinctly widened to auricled leaf bases.

The five species of Pseudoparaphysanthus are all Asiatic. Pseudoparaphysanthus takahashii is endemic to southern China and P. moutieri is known from southern China and northern Vietnam (Wu 2011). Pseudoparaphysanthus bonianus is known from Myanmar, northern Vietnam, China, Philippines and probably the Nicobar Islands (Touw \& Ochyra 1987, Wu 2011), P. submarginatus from the Andaman Islands, Malay Peninsula, Thailand and N India (Touw 1972, Touw \& Ochyra 1987), and P. touwii is endemic to Papua New Guinea (Enroth 1992b). 
Neckeromnion clade:- - This clade is divided into two subclades that are morphologically fairly consistent among themselves but differ from each other.

Neckeromnion calcutense and $N$. urocladum form a clade. They were treated and described in detail in Pinnatella by Enroth (1994b), although the first-mentioned was earlier placed in Neckeropsis by the same author (Enroth 1991). The clade is characterized by often arcuate, sparsely branched stems, especially in $P$. calcutensis. The leaves are generally ovate-lingulate and symmetric to somewhat asymmetric and have a single costa, which in $P$. calcutensis vanishes just below leaf apex and in P. uroclada reaches c. 2/3-4/5 of leaf length. The erect, symmetric capsules are well exserted on setae $2.3-4.3 \mathrm{~mm}$ long and distally mammillose. Neckeromnion calcutense has very distinct inframarginal limbidia in the leaves, not unlike those in Pinnatella alopecuroides (Mitt.) M. Fleisch. (cf. Enroth 1994b) or in the Pseudoparaphysanthus clade treated in the present paper.

All three species in the other clade, Neckeromnion gracilentum, N. lepineanum, and N. calcicolum, are dioicous, lax, sparsely branched, and have deeply and regularly undulate, glossy leaves. There are several species in Neckeropsis s. str. with deeply undulate leaves ( $N$. exserta, $N$. fimbriata, $N$. foveolata, $N$. crinita, $N$. andamana, $N$. undulata), but they are all autoicous, having the perigonia and perichaetia in the same plants but on different branches, or synoicous (Touw 1962, Buck 1998).

Neckeromnion lepineanum and $N$. calcicolum form a clade with full support. They are in fact difficult to distinguish from each other if mature sporophytes or post-fertilization perichaetial leaves are lacking (e.g., Touw 1962, 1972). In $N$. lepineanum the capsule is immersed among perichaetial leaves that are to $4.5 \mathrm{~mm}$ long, while $N$. calcicolum has a shortly exserted capsule and the perichaetial leaves are to $1.5 \mathrm{~mm}$ long (Touw 1962). Both species have a short, weak costa in the leaves.

Neckeromnion gracilentum is slightly more discordant in this clade. It differs from the two other species in being smaller and more slender, and in having a strong and long, simple costa in the leaves, which are distinctly auricled at the base. The sporophytes are unknown.

Four of the five species of Neckeromnion are exclusively Asian, or nearly so. Neckeromnion calcutense is known from Sri Lanka, India, Bhutan, Burma and Thailand (Enroth 1994). Neckeromnion urocladum was first described (Mitten 1859, as Neckera uroclada Mitt.) and long known only from Myanmar (= Burma; Enroth 1994b); however, Neckeropsis gracilis, described from Thailand (Noguchi 1972) and soon afterwards reported from Myanmar (Touw 1972, Tan \& Iwatsuki 1993), is a taxonomic synonym of P. uroclada (see Taxonomic and nomenclatural changes below). This specimen examined by us represents the first record of $N$. urocladum from Laos: "Prov. Vientiane, Vang Vieng, 102 $26^{\prime} 01$ "N 18 ${ }^{\circ} 55^{\prime} 35^{\prime \prime}$ E, cave entrance", 12 Dec. 2010, A. Vanderpoorten LAO154 (H).

Neckeromnion lepineanum is distributed from E Africa through tropical Asia to the Pacific, the easternmost localities being in Hawaii, Society Islands and Marquesas Islands (Enroth 1989). Its sister N. calcicolum has a much narrower distribution, as it is known only from Japan and China (Wu 2011). Neckeromnion gracilentum has been recorded from the Nicobar Islands and S Thailand through the SE Asian archipelago to New Guinea and Samoa in the east (Enroth 1989).

Noguchiodendron:- - The only species in Noguchiodendron, N. sphaerocarpum, was sequenced for this study and the phylogenetic results confirm its generic position among the Neckeraceae and sister to Taiwanobryum (Fig. 1). The latter genus in its current circumscription (Olsson et al. 2010) is fairly morphologically heterogeneous. All of the six species are stipitate-frondose, but for example the plant size, leaf shape and costa length vary considerably. Originally (Ninh \& Pócs 1981) Noguchiodendron was thought to be close to Homaliodendron sect. Homaliodendron as defined by Fleischer (1906-1908) and Ninh (1984), which is the same as Homaliodendron s. str. of Olsson et al. (2010). The main differences between Noguchiodendron and Homaliodendron, used to justify establishing the former genus in the first place, were tabulated by Ninh \& Pócs (1981). The most significant of the generic differences are: stem central strand present in Noguchiodendron, lacking in Homaliodendron; branches of frond curved in Noguchiodendron, straight in Homaliodendron; capsule subglobose in Noguchiodendron, ovoid to cylindrical in Homaliodendron; and annulus well differentiated in Noguchiodendron, not or weakly differentiated in Homaliodendron. There are some additional differences in the shape of the exothecial cells, papillosity of the exostome teeth, shape of the endostome segments, and spore size; however, such differences are generally considered specific rather than generic.

Noguchiodendron sphaerocarpum remains a morphologically distinct taxon also in its new placement near Taiwanobryum. The plants are about as large as those of Taiwanobryum crenulatum (Harv.) S. Olsson, Enroth \& D. Quandt and T. speciosum Nog. (the generitype); the other species currently placed in Taiwanobryum are much smaller. However, $N$. sphaerocarpum differs from the above-mentioned large species by several characters: the presence of a stem central strand, the asymmetric leaves, the essentially non-porose upper laminal cells, the subglobose capsule, and the well differentiated annulus. There are also some notable similarities among the three large taxa: the numerous, 
appressed stipe leaves, the coarsely serrate upper leaf margins, the long single costa, the distinct, small and mostly rectangular alar cells, and the long-exserted capsules, the setae being c. $1 \mathrm{~cm}$ long in $T$. crenulatum, $1.5 \mathrm{~cm}$ in $T$. speciosum, and 2-2.7 cm in Noguchiondendron (Ninh \& Pócs 1981; we have not seen the sporophytes of the latter taxon). It might be mentioned that in those taxa of Taiwanobryum for which the sporophytes are known (T. speciosum, $T$. crenulatum and T. mucronatum (Bosch \& Sande Lac.) S. Olsson, Enroth \& D. Quandt) the seta is distinctly mammillose in the upper part, but according to Ninh \& Pócs (1981) the seta of Noguchiodendron is smooth.

Based on our results, placing Noguchiodendron in a monophyletic Taiwanobryum would seem possible, but that solution would render the already morphologically heterogeneous Taiwanobryum even more so. We consider Noguchiodendron worthy of recognition at the generic level, based especially on the very long and apparently smooth vs. mammillose seta, subglobose vs. ovoid or cylindric capsules, and the well differentiated vs. not or poorly differentiated annulus.

\section{Taxonomic and nomenclatural changes}

Neckeropsis formosica (Broth. \& Yasuda) S. Olsson, Enroth, Huttunen \& D. Quandt, comb. nov.

Basionym: Himantocladium formosicum Broth. \& Yas., Rev. Bryol. 53: 2. 1926.

Illustrations: Wu (2011: plate 369, figs. 1-8, as Himantocladium formosicum).

Pengchengwua S. Olsson, Enroth, Huttunen \& D. Quandt, gen. nov.

Type: Pengchengwua obtusata (Mont.) S. Olsson, Enroth, Huttunen \& D. Quandt

Etymology: We are pleased to name this genus after our colleague Prof. Peng-Cheng (Pang-cheng) Wu (Beijing), who has contributed so much to Chinese bryology.

Description: Plants medium-sized to fairly robust, green to yellowish green, slightly glossy, often forming flat mats. Stems not stipitate, arising from creeping stolons, simple or sparsely and complanately branched. Stem and branch leaves imbricate, more or less complanate, distinctly undulate, asymmetrically lingulate, acroscopic side of leaf base distinctly decurrent, apices mostly rounded, margins crenulate at apex, entire elsewhere. Costa single, reaching to midleaf, sometimes shorter and/or bifurcate. Leaf cells smooth, relatively incrassate, pellucid, apical ones nearly isodiametric, quadrate to rhomboid or penta-to hexagonal, becoming more elongate towards leaf base, basal ones with porose walls. Branch primordia covered with broad embryonic leaves; pseudoparaphyllia few, short and few-celled, filiform, sometimes mixed with leaf-like, lanceolate ones. Dioicous (possibly polyoicous), sporophytes uncommon. Inner post-fertilization perichaetial leaves to c. $2.5 \mathrm{~mm}$ long. Seta $0.5 \mathrm{~mm}$ long, capsules oblong to narrowly ovoid, erect, symmetric, ;mmersed; apophysal stomata absent. Peristome double, neckeroid, exostome teeth smooth or finely papillose, endostome segments as long as teeth, with elongate perforations. Calyptra hairy. Spores 15-25 $\mu \mathrm{m}$, faintly papillose.

Pengchengwua obtusata (Mont.) S. Olsson, Enroth, Huttunen \& D. Quandt, comb. nov.

Basionym: Neckera obtusata Mont. Ann. Sci Nat. Bot. Sér. 2, 19:240. 1843 (Neckeropsis obtusata (Mont.) M. Fleisch. in Broth, Nat. Pfl. ed. 2, 11: 187).

Illustrations (as Neckeropsis obtusata): Noguchi (1989: fig. 313); Wu (2011: plate 386, figs. 1-6).

Planicladium S. Olsson, Enroth, Huttunen \& D. Quandt, gen. nov.

Type: Planicladium nitidulum (Mitt.) S. Olsson, Enroth, Huttunen \& D. Quandt

Etymology: In reference to the gametophytes with strongly complanate leaves and appearance.

Description: Plants medium-sized to fairly robust, yellowish green to brownish, mostly strongly glossy, forming flat mats. Stems not or only indistinctly stipitate, arising from creeping stolons, simple or sparsely and complanately branched. Stipe leaves smaller than stem leaves. Stem and branch leaves imbricate, strongly complanate, plane or somewhat homomallous, asymmetric, lingulate to spathulate, apices rounded or truncate to broadly obtuse, often apiculate, margins crenulate or serrulate at apex, mostly entire elsewhere. Costa single, reaching to midleaf or ending just below leaf apex, sometimes shorter and/or bifurcate. Leaf cells relatively incrassate, pellucid, apical ones rhomdoid to elliptic or hexagonal, becoming more elongate towards leaf base, basal ones with more or less distinctly porose 
walls; inframarginal limbidium absent or short and weakly differentiated at basiscopic side of leaf. Branch primordia covered with broad embryonic leaves; pseudoparaphyllia absent. Dioicous, sporophytes uncommon (not seen by us in P. semperianum). Inner post-fertilization perichaetial leaves to c. $3 \mathrm{~mm}$ long. Seta $0.5-1 \mathrm{~mm}$ long, capsules oblong to narrowly ovoid, erect, symmetric, immersed or shortly exserted; apophysal stomata absent. Peristome double, neckeroid; exostome teeth papillose above, striolate below, endostome segments about as long as teeth, perforate. Calyptra hairy. Spores $12-20 \mu \mathrm{m}$, faintly papillose.

Planicladium semperianum (Hampe ex Müll. Hal.) S. Olsson, Enroth, Huttunen \& D. Quandt, comb. nov.

Basionym: Neckera semperiana Hampe ex Müll. Hal., Bot. Zeit. 20: 381. 1862 (Homalia semperiana (Hampe ex Müll. Hal.) Paris, Ind. Bryol. ed. 2, 2: 321. 1904. Himantocladium semperianum (Hampe ex Müll. Hal.) Broth. ex Paris, Coll. Nom. Broth. 13. 1909. Homaliodendron semperianum (Hampe ex Müll. Hal.) Broth., Nat. Pfl. ed. 2, 11: 192. 1925. Neckeropsis semperiana (Hampe ex Müll. Hal.). Touw, Blumea 11: 414. 1962).

Illustrations (as Neckeropsis semperiana): Touw (1962: plate 18: B, figs. 1-4); Wu (2011: plate 386, figs. 7-14).

Planicladium nitidulum (Mitt.) S. Olsson, Enroth, Huttunen \& D. Quandt, comb. nov.

Basionym: Homalia ["Omalia"] nitidula Mitt., J. Linn. Soc. Bot. 8: 155. 1864 (Neckera nitidula (Mitt.) Broth., Hedwigia 38: 228. 1899. Neckeropsis nitidula (Mitt.) M. Fleisch., Musci Fl. Buitenzorg 3: 882. 1908).

Illustrations (as Neckeropsis nitidula): Noguchi (1989: fig. 312); Wu (2011: plate 385, figs. 6-14).

Pseudoparaphysanthus (Broth.) S. Olsson, Enroth, Huttunen \& D. Quandt, stat. \& comb. nov.

Basionym: Neckera sect. Pseudoparaphysanthus Broth., Nat. Pflanzenfam. 1(3): 842. 1906 (Neckeropsis sect. Pseudoparaphysanthus (Broth.) M. Fleisch., Musci Fl. Buitenzorg 3: 876. 1907).

Lectotype (cf. Ochyra \& Enroth, 1989): Pseudoparaphysanthus moutieri (Broth. \& Paris) S. Olsson, Enroth, Huttunen \& D. Quandt

Plants medium-sized, dull or slightly glossy. Stems indistinctly stipitate, relatively rigid, sparsely and irregularly to subpinnately branched, to $5(-12) \mathrm{cm}$ long, erect or ascending, arising from creeping stolons. Stem and bracnch leaves weakly to distinctly complanate, variously twisted when dry, flat and erect-patent when wet, ovate-oblong to oblong-lingulate or obovate-lingulate, symmetric to slightly asymmetric, base decurrent or not, apex obtuse to broadly acute; leaf margins coarsely dentate to nearly entire at apex, serrulate or entire at midleafand base. Costa single, very strong, subpercurrent or percurrent. Leaf cells relatively incrassate, often opaque; inframarginal limbidia consisting of elongate, linear cells distinct from leaf base to apex or ending slightly below apex, 3 to 6 cells wide, 1 - to 8-layered. Branch primordia covered by embryonic leaves; pseudoparaphyllia few, leaf-like, lanceolate, to c. $150 \mu \mathrm{m}$ long. Presumably dioicous, sporophytes rare (known only from P. moutieri and P. boniana; description based on Touw \& Ochyra 1987). Post-fertilization inner perichaetial leaves to $2.7 \mathrm{~mm}$ long. Capsule symmetric, ovoid, erect. Seta c. 0.3 long and capsule immersed, c. $0.8 \times 0.8 \mathrm{~mm}$ (P. moutieri), or seta $1.6 \mathrm{~mm}$ long, capsule exserted, c. $1.3-1.5 \mathrm{~mm}$ long (P. boniana); apophysal stomata absent. Peristome double, neckeroid; exostome teeth lanceolate-subulate, finely papillose below, smooth to faintly papillose above, median perforations indistinct to absent; endostome segments linear to lanceolate, papillose, indistinctly to strongly perforated. Operculum conical, with a straight to oblique beak. Calyptra (known for P. moutieri) cucullate, bearing paraphyses at base. Spores $18-30 \mu \mathrm{m}$, finely papillose.

Pseudoparaphysanthus moutieri (Broth. \& Paris) S. Olsson, Enroth, Huttunen \& D. Quandt, comb. nov.

Basionym: Sciaromium moutieri Broth. \& Paris, Rev. Bryol. 27: 78. 1900 (Neckera moutieri (Broth. \& Paris) Broth., Nat. Pfl. 1(3): 842. 1906. Neckeropsis moutieri (Broth. \& Paris) M. Fleisch., Musci Fl. Buitenzorg 3: 882. 1908).

Illustrations (as Neckeropsis moutieri): Touw \& Ochyra (1987: fig. 1); He \& Zhang (2007: fig. 1); Wu (2011: plate 385, figs. 1-5).

Pseudoparaphysanthus takahashii (Higuchi, Iwatsuki, Ochyra \& Li) S. Olsson, Enroth, Huttunen \& D. Quandt, comb. nov.

Basionym: Neckeropsis takahashii Higuchi, Iwatsuki, Ochyra \& Li, Nova Hedwigia 48: 432. 1989.

Illustrations: Higuchi et al. (1989: figs. 1-29, as Neckeropsis takahashii).

Pseudoparaphysanthus bonianus (Besch.) S. Olsson, Enroth, Huttunen \& D. Quandt, comb. nov.

Basionym: Porotrichum bonianum Besch., Bull. Soc. Bot. France 34: 97. 1887 (Pinnatella boniana (Besch.) Pócs, Egri Tanárképzö Föisk. Tud. Közlem. 3: 471. 1965. Neckeropsis boniana (Beschg.) Touw \& Ochyra, Lindbergia 13: 101. 1987).

Illustrations (as Neckeropsis boniana): Touw \& Ochyra (1987: fig. 2); Wu (2011; plate 383, figs. 1-7).

64 • Bry. Div. Evo. 38 (2) (C 2016 Magnolia Press

OLSSON ET AL. 
Pseudoparaphysanthus submarginatus (Cardot ex Touw) S. Olsson, Enroth, Huttunen \& D. Quandt, comb. nov. Basionym: Neckeropsis submarginata Cardot ex Touw, Blumea 11: 417. 1962.

Illustrations: Touw (1962: plate 21, A as Neckeropsis submarginata).

Pseudoparaphysanthus touwii (Ochyra \& Enroth) S. Olsson, Enroth, Huttunen \& D. Quandt, comb. nov. Basionym: Neckeropsis touwii Ochyra \& Enroth, Ann. Bot. Fennici 26: 128. 1989.

Illustrations: Ochyra \& Enroth (1989: fig. 1 \& 2)

Neckeromnion S. Olsson, Enroth, Huttunen \& D. Quandt, gen. nov.

Type: Neckeromnion lepineanum (Mont.) S. Olsson, Enroth, Huttunen \& D. Quandt

Description: Plants medium-sized to very robust (sometimes several dozens of $\mathrm{cm}$ long). Stems not or indistinctly stipitate, more or less flexuose and arcuate, sparsely and irregularly branched, arising from creeping stolons. Flagelliform, microphyllous branches (vegetative propagulae) sometimes present. Stem and branch leaves complanate to erect-patent, slightly to distinctly asymmetric, lingulate to ovate-lingulate, oblong or subelliptic, mostly not auricled, from shallowly and irregularly to deeply and regularly undulate with lunate undulations, or smooth to plicate, leaf apices obtuse to rounded or truncate or slightly emarginate, sometimes indistinctly apiculate; leaf margins nearly entire throughout or crenulate to serrulate near apex. Costa nearly absent to short and faint, sometimes bifurcate, to simple, strong and reaching to near leaf apex. Leaf cells smooth, relatively thick-walled, pellucid, apical ones nearly isodiametric, median and basal cells elongate, basal cells often longer in basiscopic (proximal) side of leaf than in acroscopic, marginal cells usually shorter in 1-2 row(s), inframarginal limbidia of elongate cells sometimes present and sharply demarcated, alar cells indistinct but much shorter than adjacent laminal cells, short-rhomboid or rectangular to irregular. Branch primordia covered by embryonic leaves; pseudoparaphyllia absent or few, small, subulate to lanceolate. Dioicous. Post-fertilization inner perichaetial leaves from $0.9 \mathrm{~mm}$ (with no post-fertilization growth) to $4.5 \mathrm{~mm}$ long (with strong post-fertilization growth). Seta from 0.5 to $4.3 \mathrm{~mm}$ long, yellowish, smooth or slightly mammillose in upper part, capsule erect, symmetric, ovoid to nearly elliptic or cylindric, 1.4-2.0 mm long; apophysal stomata absent or few, phaneropore. Peristome double; exostome teeth lanceolate-subulate, lanceolate, dorsal side spiculose-papillose nearly throughout, often with median perforations; endostome segments as long as teeth or nearly so, on a low basal membrane, subulate, with elongate median perforations, faintly papillose throughout. Operculum conical, obliquely rostrate. Calyptra cucullate, with long paraphyses attached to its lower part. Spores c. $12-30 \mu \mathrm{m}$, faintly papillose.

Neckeromnion calcutense (M. Fleisch.) S. Olsson, Enroth, Huttunen \& D. Quandt, comb. nov.

Basionym: Pinnatella calcutensis M. Fleisch., Hedwigia 45: 84. 1906 (Pinnatella alopecuroides var. calcutensis (M. Fleisch.) Gangulee, Mosses Eastern India 5: 1440. 1976. Neckeropsis calcutensis (M. Fleisch.) Enroth, Acta Bryolichenol. Asiatica 2: 9. 1991).

Illustrations: Gangulee (1976: fig. 714, as Pinnatella alopecuroides var. calcutensis); Enroth (1994b: fig. 21, as Pinnatella calcutensis).

Neckeromnion urocladum (Mitt.) S. Olsson, Enroth, Huttunen \& D. Quandt, comb. nov.

Basionym: Neckera uroclada Mitt., J. Proc. Linn. Soc., Suppl. Bot. 1: 122 (Himantocladium urocladum (Mitt.) M. Fleisch., Musci Fl. Buitenzorg 3: 888. 1908. Pinnatella uroclada (Mitt.) Enroth, Acta Bot. Fennica 151: 57. 1994).

Neckeropsis gracilis Nog., Lindbergia 1: 177. 1972, syn. nov. Holotype: Thailand. Chantaburi, Kao Sabab, 1-300 m, 18. Jan. 1958 leg. Th. Sørensen et al. 7254 a (C!). Paratype: Same locality and date, leg. Th. Sørensen et al. $7254 \mathrm{~b}$ (C!).

Illustrations: Noguchi (1972: fig. 2, as Neckeropsis gracilis); Enroth (1994b: fig. 22, as Pinnatella uroclada).

Neckeromnion calcicolum (Nog.) S. Olsson, Enroth, Huttunen \& D. Quandt, comb. nov.

Basionym: Neckeropsis calcicola Nog. J. Hattori Bot. Lab. 16: 124. 1956.

Illustrations (as Neckeropsis calcicola): Noguchi (1989: fig. 314); Wu (2011: plate 383, figs. 8-14).

Neckeromnion gracilentum (Bosch \& Sande Lac.) S. Olsson, Enroth, Huttunen \& D. Quandt, comb. nov.

Basionym: Neckera gracilenta Bosch \& Sande Lac., Bryol. Jav. 2: 62. 1863 (Neckeropsis gracilenta (Bosch \& Sande Lac.) M. Fleisch., Musci Fl. Buitenzorg 3: 876. 1908).

Illustrations (as Neckeropsis gracilenta): Touw (1962: plate 5, figs. 3-6); Enroth (1989: fig. 2a-h). 
Neckeromnion lepineanum (Mont.) S. Olsson, Enroth, Huttunen \& D. Quandt, comb. nov.

Basionym: Neckera lepineana Mont., Ann. Sci. Nat. Bot. Sér. 10: 107. 1848 (Neckeropsis lepineana (Mont.) M. Fleisch., Musci Fl. Buitenzorg 3: 879. 1908).

Illustrations (as Neckeropsis lepineana): Touw (1962: plate 3; plate 5, figs. 1 \& 2); Enroth (1989: fig. 1); Wu (2011: plate 384, figs. 9-15).

\section{Acknowledgements}

SO acknowledges financial support from the Oskar Öflund Society and wish to thank Prof. Christoph Neinhuis at the Dresden University of Technology and Helena Korpelainen at the University of Helsinki for supporting the laboratory work. Sincere thanks are due to Claudia Schütte (Nees) for lab assistance. We acknowledge funding by the German Science Foundation (DFG QU 153/8-1). This research was supported by a Marie Curie Intra-European Fellowship (MEIF-CT-2005-009452) and a Marie Curie Reintegration Grant (PERG03-GA-2008-230953) within the 6th European Community Framework Program as well as a post doctoral researcher grant from the Academy of Finland (project no. 121373) for $\mathrm{SH}$.

\section{References}

Akiyama, H. (1992) Rheophytes of bryophytes in wet tropics of Southeastern Asia. Natural Environment Science Research 5: $43-55$.

Akiyama, H. (1993) Taxonomic studies of mosses of Seram and Ambon (Moluccas, East Malaysia) collected by Indonesian-Japanese botanical expeditions. VII, Lembophyllaceae, Splachnaceae, Myuriaceae, Neckeraceae, Brachytheciaceae, Amblystegiaceae and Sematophyllaceae, with additions to previous reports on Dicranaceae and Pterobryaceae. Journal of the Faculty of Science, University of Tokyo, Section III, 15: 219-254.

Borsch, T. \& Quandt, D. (2009) Mutational dynamics and phylogenetic utility of non-coding plastid DNA. Plant Systematics and Evolution 282: 169-199. https://doi.org/10.1007/s00606-009-0210-8

Brotherus, V.F. (1925) Neckeraceae. In: Engler, A. \& Prantl, K. (Eds.) Die natürlichen Pflanzenfamilien, ed. 2, vol. 11, part 2, Musci (Laubmoose). W. Engelmann, Leipzig, pp. 178-202.

Buck, W.R. (1998) Pleurocarpous mosses of the West Indies. Memoirs of the New York Botanical Garden 82: 1-400.

De Sloover, J.L. (1977) Note de bryologie africaine VIII. Neckera, Neckeropsis. Bulletin du Jardin Botanique National de Belgique 47: $31-48$. https://doi.org/10.2307/3667979

Ellis, L.T., Agcagil, E., Kırmac1, M., Aleffi, M., Bakalin, A., Bednarek-Ochyra, H., Cykowska-Marzencka, B., Stryjak-Bogacka, M., Bojaca, G.F.P., Fantacelle, L.B., Araújo, C.A.T., Maciel-Silva, A.S., Silva, J.B., Calleja, J.A., Cano, M.J., Diaz, J.C., Gabriel, R., Dias dos Santos, N., Enroth, J., Erzberger, P., Garilleti, R., Hájek, M., Hedenäs, L., Heras, P., Infante, M., Kiebacher, T., Koczur, A., Krawczyk, R., Kučera, J., Lebouvier, M., Lüth, M., Mazimpaka, V., Vigalondo, B., Lara, F., Nagy, J., Németh, Cs., Kovács, A., Nobis, M., Wegrzyn, M., Wietrzyk, P., Norhazrina, N., Vanderpoorten, A., Nowak, A., Poponessi, S., Gigante, D., Venanzoni, R., Plášek, V., Germano, S.R., Schäfer-Verwimp, A., Sérgio, C., Claro, D., Garcia, C.A., Shirzadian, S., Darzikolaei, S.A., Stebel, A., Suleiman, M., Yong, K.-T., Virchenko, V.M., Vončina, G., Yoon, Y.-J., Choi, H.-G. \& Kim, J.H. (2016) New national an regional bryophyte records, 49. Journal of Bryology 38: 327-347.

https://doi.org/10.1080/03736687.2016.1225777

Enroth, J. (1992a) Notes on the Neckeraceae (Musci). 13. Taxonomy of the genus Himantocladium. Annales Botanici Fennici $29:$ 79-88.

Enroth, J. (1992b) Notes on the Neckeraceae (Musci). 14-16. The identities of Porothamnium undulatifolium and Baldwiniella tibetana, plus the second record of Neckeropsis touwii. Annales Botanici Fennici 28: 249-251.

Enroth, J. (1993) Notes on the Neckeraceae (Musci). 17. A taxonomic study on the genus Neckeropsis in Africa. Journal of the Hattori Botanical Laboratory 73: 159-173.

Enroth, J. (1994a) Additions to the moss floras of Solomon Islands and several countries of tropical Asia. Tropical Bryology 9: 25-30. https://doi.org/10.11646/bde.9.1.5

Enroth, J. (1994b) A taxonomic monograph of the genus Pinnatella (Neckeraceae, Bryopsida). Acta Botanica Fennica 151: 1-90.

Enroth, J. (1995) Notes on the Neckeraceae (Musci). 21-22. Porotrichopsis flacca and Neckeropsis inundata. Fragmenta Floristica et Geobotanica 40: 181-188. 
Enroth, J. (1996) Contributions to tropical Asian Neckeraceae (Bryopsida). Hikobia 12: 1-7.

Enroth, J. (1999) A review of the rheophytic Neckeraceae. Haussknechtia Beiheft 9: 121-127.

Enroth, J. \& Magill, R.E. (1994) Neckeropsis pocsii (Neckeraceae, Musci), a new species from Comoro Islands. The Bryologist 97 : 171-173. https://doi.org/10.2307/3243755

Enroth, J., Olsson, S., He, S., Shevock, J.R. \& Quandt, D. (2010) When morphology and molecules tell us different stories, part 2: Pinnatella homaliadelphoides (Neckeraceae), a new moss species from China and India. Tropical Bryology 31: 67-75. https://doi.org/10.11646/bde.31.1.12

Fleischer, M. (1906-1908) Die Musci der Flora von Buitenzorg, vol. 3. E.J Brill, Leiden, pp. I-XXIV, 645-113.

Florschütz-De Waard, J. (1986) Musci (Part II). In: Stoffers, A.L. \& Lindeman, J.C. (Eds.) Flora of Suriname, vol. 1, part 1. E. J. Brill, Leiden, pp. 273-360.

Gangulee, H.C. (1976) Mosses of Eastern India and adjacent regions, Fasc. 5: Isobryales. Published by the author, Calcutta, pp. XXVIIXXXV, 1135-1462.

He, S. \& Zhang, L. (2007) Neckeropsis moutieri (Neckeraceae), a Southeast Asian species new to China. Journal of Tropical and Subtropical Botany 15: 545-548.

Higuchi, M., Iwatsuki, Z., Ochyra, R. \& Li, X.-J. (1989) Neckeropsis takahashii (Neckeraceae, Musci), a new species from Yunnan, China. Nova Hedwigia 48: 431-435.

Huelsenbeck, J.P. \& Ronquist, F. (2001) MrBayes: Bayesian inference of phylogenetic trees. Bioinformatics 17: 754-755. https://doi.org/10.1093/bioinformatics/17.8.754

Huelsenbeck, J.P., Larget, B., Miller, R.E. \& Ronquist, F. (2002) Potential applications and pitfalls of bayesian inference of phylogeny. Systematic Biology 51:673-688. https://doi.org/10.1080/10635150290102366

Huelsenbeck, J.P., Ronquist, F., Nielsen, R. \& Bollback, J.P. (2001) Bayesian inference of phylogeny and its impact on evolutionary biology. Science 294: 2310-2314. https://doi.org/10.1126/science.1065889

Kelchner, S.A. (2000) The evolution of non-coding chloroplast DNA and its application in plant systematics. Annals of the Missouri Botanical Garden 87: 482-498. https://doi.org/10.2307/2666142

Laenen, B., Machac, A., Gradstein, S.R., Shaw, B., Patiño, J., Desamoré, A., Goffinet, B., Cox, C.J., Shaw, A.J. \& Vanderpoorten, A. (2016) Increased diversification rates follow shifts to bisexuality in liverworts. New Phytologist 210: 1121-1129. https://doi.org/10.1111/nph.13835

Miller M.A., Pfeiffer, W. \& Schwartz, T. (2010) Creating the CIPRES Science Gateway for inference of large phylogenetic trees. Proceedings of the Gateway Computing Environments Workshop (GCE) 14 Nov 2010, pp. 1-8. https://doi.org/10.1109/GCE.2010.5676129

Mitten, W. (1859) Musci Indiae Orientalis; an enumeration of the mosses of the East Indies. Journal of the Proceedings of the Linnean Society, Supplement to Botany 1: 1-171.

Mitten, W. (1868) A list of the Musci collected by the Rev. Thomas Powell in the Samoa or Navigator's Islands. Journal of the Linnean Society, Botany 10: 166-195, plates 5 \& 6.

Müller, K.F. (2005) SeqState - primer design and sequence statistics for phylogenetic DNA data sets. Applied Bioinformatics 4: 65-69.

Müller, K.F., Quandt, D., Müller, J. \& Neinhuis, C. (2005) PhyDE ® 0.995: Phylogenetic Data Editor. Available from: http://www.phyde.de (accessed 29 December 2016)

Ninh, T. (1984) A revision of Indochinese Homaliodendron. Journal of the Hattori Botanical Laboratory 57: 1-39.

Ninh, T. \& Pócs, T. (1981) Noguchiodendron, a new genus of the moss family Neckeraceae. Acta Botanica Academiae Scientiarum Hungaricae 27 (1-2): 161-168.

Nixon, K.C. (1999) The Parsimony Ratchet, a new method for rapid parsimony analysis. Cladistics 15: 407-414. https://doi.org/10.1111/j.1096-0031.1999.tb00277.x

Noguchi, A. (1950) A review of the Leucodontinae and Neckerinae of Japan, Loo Choo and of Formosa, III. Journal of the Hattori Botanical Laboratory 4: 1-48.

Noguchi, A. (1972) Mosses of Thailand. Lindbergia 1: 169-183.

Ochyra, R. (1986) A taxonomic study of the genus Handeliobryum Broth. (Musci, Thamnobryaceae). Journal of the Hattori Botanical Laboratory 61: 65-74.

Ochyra, R. \& Shevock, J.R. (2012) A fruiting plant of Handeliobryum sikkimense (Bryopsida, Thamnobryaceae) from Yunnan, China. Nova Hedwigia 94: 307-321. https://doi.org/10.1127/0029-5035/2012/0021 
Olsson, S., Buchbender, V., Enroth, J., Huttunen, S., Hedenäs, L. \& Quandt, D. (2009a) Evolution of the Neckeraceae: resolving the backbone phylogeny. Systematics and Biodiversity 7: 419-432. https://doi.org/10.1017/S1477200009990132

Olsson, S., Buchbender, V., Enroth, J., Hedenäs, L., Huttunen, S. \& Quandt, D. (2009b) Phylogenetic analyses reveal high levels of polyphyly among pleurocarpous lineages as well as novel clades. The Bryologist 112: 447-466. https://doi.org/10.1639/0007-2745-112.3.447

Olsson, S., Buchbender, V., Enroth, J., Hedenäs, L., Huttunen, S. \& Quandt, D. (2010) Phylogenetic relationships in the "Pinnatella" clade of the moss family Neckeraceae (Bryophyta). Organisms, Diversity \& Evolution 10 (2): 107-122. https://doi.org/10.1007/s13127-010-0017-z

Olsson, S., Enroth, J., Buchbender, V., Hedenäs, L., Huttunen, S. \& Quandt, D. (2011) Neckera and Thamnobryum (Neckeraceae. Bryopsida): Paraphyletic assemblages. Taxon 60: 36-50.

Quandt, D. \& Stech, M. (2004) Molecular evolution of the trnTUGU-trnFGAA region in bryophytes. Plant Biology 6: $545-554$. https://doi.org/10.1055/s-2004-821144

Quandt, D., Müller, K.F. \& Huttunen, S. (2003) Characterisation of the chloroplast DNA psbT-H region and the influence of dyad symmetrical elements on phylogenetic reconstructions. Plant Biology 5: 400-410. https://doi.org/10.1055/s-2003-42715

Rambaut, A, Suchard, M.A., Xie, D. \& Drummond, A.J. (2014) Tracer v1.6. Available from: http://beast.bio.ed.ac.uk/Tracer (accessed 29 December 2016)

Reichardt, H.W. (1868) Neckeropsis, eine neue Laubmoos-Gattung. Verhandlungen der zoologisch-botanischen Gesellschaft in Wien 18: 191-192.

Sastre de Jesús, I. (1987) A revision of the Neckeraceae Schimp. and the Thamnobryaceae Marg. \& Dur. in the neotropics. Unpublished PhD-thesis, City University of New York.

Shevock, J.R., Ochyra, R. \& Buck, W.R. (2006) Observations on the ecology and distribution of Hydrocryphaea wardii, a southeast Asian monospecific genus, reported new for China from Yunnan province. Journal of the Hattori Botanical Laboratory 100: 407-418.

Simmons, M.P. \& Ochoterena, H. (2000) Gaps as characters in sequence-based phylogenetic analyses. Systematic Biology 49: 369-381. https://doi.org/10.1093/sysbio/49.2.369

Stamatakis, A. (2006) RAxML-VI-HPC: Maximum likelihood-based phylogenetic analyses with thousands of taxa and mixed models. Bioinformatics 22: 2688-2690. https://doi.org/10.1093/bioinformatics/bt1446

Stamatakis, A., Hoover, P. \& Rougemont, J. (2008) A rapid bootstrap algorithm for the RAxML Web servers. Systematic Biology 57: $758-771$.

https://doi.org/10.1080/10635150802429642

Stearn, W.T. (1993) Botanical Latin, 4th edn. David \& Charles, Newton Abbot, 566 pp.

Stöver, B.C. \& Müller, K.F. (2010) TreeGraph 2: Combining and visualizing evidence from different phylogenetic analyses. BMC Bioinformatics 11: 7 . https://doi.org/10.1186/1471-2105-11-7

Swofford, D.L. (2002) PAUP*. Phylogenetic analysis using parsimony (*and other methods). Version 4b10. Sinauer Associates, Sunderland, Massaschusetts.

Tan, B.C. \& Iwatsuki, Z. (1993) A checklist of Indochinese mosses. Journal of the Hattori Botanical Laboratory 74: 325-405.

Touw, A. (1962) Revision of the moss-genus Neckeropsis (Neckeraceae). 1. Asiatic and Pacific species. Blumea 11: 373-425.

Touw, A. (1972) Additional notes on Neckeropsis. Lindbergia 1: 184-188.

Touw, A. \& Ochyra, R. (1987) Additional notes on Neckeropsis 2. Lindbergia 13: 97-104.

Wijk, R. van der, Margadant, W.D. \& Florschütz, P.A. (1964) Index Muscorum 3 (Hypnum-O). Regnum Vegetabile 33: 1-529.

Wu, P. (2011) Neckeraceae. In: Wu, P. \& Crosby, M.R. (Eds.) Moss Flora of China, English Version, vol. 5. Erpodiaceae-Climaciaceae. Science Press, Beijing \& Missouri Botanical Garden Press, St. Louis, pp. 319-368. 
Appendix 1. Species names, voucher information, and EMBL or GenBank accession numbers for the sequences used in the molecular analyses (rps $4-\operatorname{trn} T \& \operatorname{trn} L-\operatorname{trnF}$; rpl16; ITS1 \& 2, respectively). A dash (-) indicates a missing sequence. In two cases sequences were submitted to GenBank in previous studies and thus the accession numbers for $r p s 4$-trnT-trnL-trnF are composed of two different accession numbers. Sequences newly generated for this study are marked with an asterisk (*).

Alleniella besseri (Lob.) S. Olsson, Enroth \& D. Quandt; Olsson 107 (herb. Quandt); FM210294, FM161003, FM161156. Alleniella complanata (Hedw.) S. Olsson, Enroth \& D. Quandt; Buchbender 204 (herb. Buchbender); AM990413, FM161005, FM161158. Alleniella hymenodonta (Müll. Hal.) S. Olsson, Enroth \& D. Quandt; H3206871 (H); FM210302, FM161011, FM161164. Bissetia lingulata (Mitt.) Broth.; H3194160 (H); AM990346, FM160949, FM161079. Caduciella mariei (Besch.) Enroth; Koponen 28035 (H); FM210282, FM160953, FM161084. Camptochaete arbuscula var. tumida (Sm.) Reichardt; Streimann 51408 (H); AM990353, FM160955, FM161087. Circulifolium exiguum (Bosch \& Sande Lac.) S. Olsson, Enroth \& D. Quandt; B263509 (B); AM990389, FM160984, FM161130. Circulifolium microdendron (Mont.) S. Olsson, Enroth \& D. Quandt; Redfearn, Jr. 35901 (H); AM990390, FM160987, FM161133. Curvicladium kurzii (Kindb.) Enroth; Akiyama Th-85 (NYBG); FM210285, AM990362 trnlF, FM160959, FM161093. Dolichomitriopsis diversiformis (Mitt.) Nog.; Nedoluzhko s.n. (H, MHA); AM990362, trnlF AF397777, FM160963, FM161098. Forsstroemia neckeroides (Hornsch.) Paris; H3064115 (H); FN868963, FN868978, FN868972. Forsstroemia trichomitria (Hedw.) Lindb.; Streimann \& Pócs 65120A (herb. Buchbender); AM990365, FM160968, FM161103. Handeliobryum sikkimense (Paris) Ochyra; Redfearn et al. 33981 (H); FM210287, FM160969, FM161110. Heterocladium dimorphum (Brid.) Schimp.; H3212307 (H); AM990376, FM160970, FM161115. Heterocladium procurrens (Mitt.) A. Jaeger; H3212289 (H); AM990379, FM160973, FM161118. Himantocladium giulianettii (Broth) M. Fleisch.; L0837454 (L); FN869002*, FN869019*, FN868982*. Himantocladium implanum (Mitt.) M. Fleisch.; De Sloover 21124 (NYBG); FM210289, FM160975, FM161121. Himantocladium plumula (Nees) M. Fleisch.; Tan et al. 92-232 (H); AM990381, FM160976, FM161122. Himantocladium submontanum Enroth; H3071191 (H); FN869003*, FN869020*, FN868983*. Homalia trichomanoides (Hedw.) Schimp.; Olsson 105 (herb. Quandt); AM990385, FM160980, FM161126. Homalia webbiana (Mont.) Schimp.; Müller K68 (H); AM990387, FM160982, FM161127. Homaliadelphus targionianus (Mitt.) Dixon \& P. de la Varde; Koponen et al. 55009 (H); AM990388, FM160983, FM161129. Homaliodendron flabellatum (Sm.) M. Fleisch.; H3071675 (H); FM210290, FM160985, FM161132. Homaliodendron neckeroides Broth.; H3071953 (H); FM210306, FM161015, FM161168. Homaliodendron scalpellifolium (Mitt.) M. Fleisch.; H3071976 (H); FM210292, FM160989, FM161135. Hydrocryphaea wardii Dix.; Shevock 23460 (H); FM210293, FM160992, FM161139. Lembophyllum clandestinum (H. f \& W.) Lindb.; Vitt 29644 (H); AM990401, trnLF AF397823, FM160996, FM161145. Leptodon smithii (Hedw.) F. Weber \& D. Mohr; B268385 (B); AM990403, FM160997, FM161147. Miyabea fruticella (Mitt.) Broth.; Koponen 45838 (H); AM990411, FM161001, FM161154. Miyabea rotundifolia Cardot; Tan 93-771 (H); AM990412, FM161002, FM161155. Neckera himalayana Mitt.; B253876 (B); FM210301, FM161010, FM161163. Neckera menziesii Drumm.; Halse 4878 (NYBG); FM210305, FM161014, FM161167. Neckera pennata Hedw.; H3203794 (H); AM990414, FM161016, FM161169. Neckera polyclada Müll. Hal.; Koponen 45441 (H); FM210307, FM161017, FM161170. Neckera warburgii Broth.; Bryo253855 (B); FM210311, FM161023, FM161176. Neckeromnion calcicolum (Nog.) S. Olsson, Enroth, Huttunen \& D. Quandt; Enroth 64632 (H); AM990417, FM161025, FM161178. Neckeromnion calcutense (M. Fleisch.) S. Olsson, Enroth, Huttunen \& D. Quandt; H3212832 (H); AM990418, FM161026, FM161179. Neckeromnion gracilentum (Bosch \& Sande Lac.) S. Olsson, Enroth, Huttunen \& D. Quandt; B105716 (S); FM210315*, FM161029*, FM161182*. Neckeromnion lepineanum (Mont.) S. Olsson, Enroth, Huttunen \& D. Quandt; Shevock 32240 (H); FN869006*, FN869024*, FN868987*. Neckeromnion urocladum (Mitt.) S. Olsson, Enroth, Huttunen \& D. Quandt; Schäfer-Verwimp \& Verwimp s.n. (herb. Enroth); FN869005, FN869023, FN868986. Neckeropsis andamana (Müll. Hal.) M. Fleisch.; Tan 91-267 (FH); FN869015, FN869031, FN868994. Neckeropsis beccariana (Hampe) Touw; Suleiman 3334 (BORH); FN869014*, FN869035*, FN868998*. Neckeropsis crinita (Griff.) M. Fleisch.; H3236231 (H); missing, missing, missing. Neckeropsis cyclophylla (Müll. Hal.) S. Olsson, Enroth \& Quandt; Redfearn Jr. 36081 (NYBG); FM210288, FM160974, FM161120. Neckeropsis disticha (Hedw.) Kindb.; Heras 901/93 (NYBG); FM210313, FM161027, FM161180. Neckeropsis exserta (Hook. ex Schwägr.) Broth.; PE01098512 (PE); FN869011*, FN869034*, FN868997*. Neckeropsis exserta var. scrobiculata (Nees) Touw; NYBG 01127000 (NYBG); FN869012*, FN869033*, FN868996*. Neckeropsis fimbriata (Harv.) M. Fleisch.; H3220430 (H); missing, missing, missing. Neckeropsis formosica (Broth. \& Yasuda) S. Olsson, Enroth, Huttunen \& D. Quandt; TAI B16113 (TAI); FN869001*, FN869021*, FN868984*. Neckeropsis foveolata (Mitt.) Broth.; Allen 17467A (MO); FN869004*, FN869022*, FN868985*. Neckeropsis madecassa (Besch.) M. Fleisch.; H3098198 (H); FN869007*, FN869025*, FN868988*. Neckeropsis pocsii Enroth \& Magill; H3098218 (H); FN869009*, FN869027*, FN868990*. 
Neckeropsis undulata (Hedw.) Reichardt; B238406 (B); FM210316, FM161031, FM161184. Noguchiodendron sphaerocarpum (Nog.) Ninh \& Pócs; H3214425 (H); FN869016, FN869029, FN868992. Pendulothecium punctatum (Hook. f. \& Wilson) Enroth \& S. He; Streimann 53845 (S); AM990421, FM161033, FM161187. Pengchengwua obtusata (Mont.) S. Olsson, Enroth, Huttunen \& D. Quandt; Shevock 28881 (H); FN869008*, FN869026*, FN868989*. Pinnatella alopecuroides (Mitt.) M. Fleisch.; Schäfer-Verwimp 16824 (herb. Enroth); AM990423, FM161034, FM161188. Pinnatella foreauana Thér. \& P. de la Varde; Linis 757-03 (H); FM210319, FM161037, FM161191. Pinnatella homaliadelphoides Enroth, S. Olsson, S. He, Shevock \& D. Quandt; Shevock 31181 (H); FN557038, FN557037, FN557036. Pinnatella kuehliana (Bosch \& Sande Lac.) M. Fleisch.; Müller S116 (herb. Enroth); FM20150, FM161038, FM161192. Pinnatella minuta (Mitt.) Broth.; Rikkinen et al. 32 (herb. Enroth); AM990424, FM161040, FM161194. Pinnatella taiwanensis Nog.; Koponen et al. 54169 (H); FM210321, FM161042, FM161196.Planicladium nitidulum (Mitt.) S. Olsson, Enroth, Huttunen \& D. Quandt; B105713 (S); AM990419, FM161030, FM161183. Planicladium semperianum (Hampe) S. Olsson, Enroth, Huttunen \& D. Quandt; He 40426 (MO); FN869010*, FN869028*, FN868991*. Porotrichodendron superbum (Taylor) Broth.; H3121100 (H); AM990427, FM161043, FM161198. Pseudoparaphysanthus moutieri (Broth. \& Paris) S. Olsson, Enroth, Huttunen \& D. Quandt; Liu et al. 448 (HSNU); -, FN869032*, FN868995*. Pseudoparaphysanthus takahashii Higuchi, Z. Iwats., Ochyra \& X.J. Li; He 40411 (MO); FN869013*, FN869030*, FN868993*. Rigodium pseudothuidium Dusén; H3134254 (H); AM990438, trnlF AF543547, FM161051, -. Rigodium pseudothuidium Dusén; NYBG 00892248 (NYBG); -, -, FM161210. Taiwanobryum mucronatum (Bosch \& Sande Lac.) S. Olsson, Enroth \& D. Quandt; Hedenäs MY92-22 (S); AM990425, FM161041, FM161195. Taiwanobryum speciosum Nog.; Enroth 64877 (H); AM990442, FM161055, FM161216. Thamnobryum alopecurum (Hedw.) Nieuwl. ex Gangulee; Buchbender s.n. 11. July 2003 (herb. Buchbender); AM990444, FM161056, FM161218. Thamnobryum subserratum (Hook.) Nog. \& Z. Iwats.; Enroth 64595 (H); AM990446, FM161067, FM161230. Weymouthia mollis (Hedw.) Broth.; 99-Mo2 (CHR); AM990452, FM161072, FM161237. 